\title{
Original
}

\section{Antioxidative and Hypolipidemic Effects of Dietary Green Tea Polyphenols in ddY Mice Fed Fish Oil-rich Diet}

(Received December 24, 1997)

\author{
Kyoji Yoshino*1, Takanobu Goto*1, Hisashi Kuribayashi*1, \\ Mayuko Tamura*1, Mitsuaki Sano*2, Hisashi Murata*3 \\ and Isao Tomita $* 2$
}

\begin{abstract}
(*1 Department of Chemistry and Biochemistry, Numazu College of Technology: 3600, Ooka, Numazu-shi, Shizuoka 410-8501, Japan; ${ }^{* 2}$ School of Pharmaceutical Sciences, University of Shizuoka: 52-1, Yada, Shizuoka-shi, Shizuoka 422-8002, Japan; ${ }^{* 3}$ Faculty of Agriculture, Miyazaki University: Gakuenkibanadai-nishi, Miyazaki-shi, Miyazaki 889-2155, Japan)
\end{abstract}

The antioxidative and hypolipidemic effects of green tea polyphenols (TP) in mice fed a fish oil-supplemented diet were investigated. Male ddY mice of 8 weeks old were given the following diets for 21 days: control diet (a diet supplemented with 5.0\% corn oil), a diet with $0.5 \%$ corn oil and $4.5 \%$ cod liver oil, or a diet with $0.5 \%$ corn oil, $4.5 \%$ cod liver oil, and $0.5 \%$ TP. The contents of n-3 polyunsaturated fatty acids in the liver of mice given the fish oil plus TP diet were significantly higher than those in the group given the fish oil-only diet. The hypolipidemic effect of fish oil was enhanced by additional administration of TP. Administration of the fish oil-supplemented diet with TP inhibited the increase of lipid peroxide levels caused by fish oil in the liver and serum of mice. The decrease of vitamin $\mathrm{E}$ content in the biological samples caused by fish oil feeding was also suppressed by additional TP administration. Thus, addition of $0.5 \% \mathrm{TP}$ to the fish oil-supplemented diet has significant hypolipidemic and antioxidative effects in mice.

Key words: antioxidative effect; hypolipidemic effect; green tea polyphenols; mouse; fish oils; n-3 polyunsaturated fatty acids

Administration of fish oils or oils rich in n-3 polyunsaturated fatty acids (PUFA) may reduce the risk of cardiovascular disease $\mathrm{e}^{1-3)}$. In relation to this effect, it was found that fish oil administration decreased the blood pressure of rats ${ }^{4), 5)}$, the contents of serum lipids (triglyceride and cholesterol) $)^{6)-8)}$ and the sensitivity of low density lipoprotein (LDL) to oxidation ${ }^{9)}$. The increased resistance of LDL to oxidation was thought to be due to vitamin $\mathrm{E}$ in fish oils. Conversely, it was also observed that the susceptibility of LDL to oxidation was enhanced by fish oil administration, especially when the content of vitamin $\mathrm{E}$ in the fish oil was low $^{9), 10)}$. Fish oils and $\mathrm{n}-3$ PUFA are prone to be peroxidized and therefore, dietary supplementation of fish oils often causes an increase of lipid peroxide contents in animal plasma and liver ${ }^{11-15)}$. The contents of antioxidative vitamins, especially vitamin $\mathrm{E}^{11,12), 15)-19)}$ and the activities of antioxidative enzymes ${ }^{12)}$ in animal plasma and organs are likely to be decreased by fish oil feeding. The addition of antioxidants to a fish oil- or n-3 PUFA-supplemented diet is expected to prevent these undesirable effects and to enhance the actions of fish oil or n-3 PUFA.

Plant polyphenols can prevent the lipid peroxidation of fish oils ${ }^{20-23)}$. Polyphenols in green tea leaves (Camellia sinensis L.) are strong natural antioxidants, in vivo ${ }^{24-26)}$ as well as in vitro ${ }^{27), 28)}$. They decrease the contents of lipid peroxides in mouse or rat blood ${ }^{25)}$, 29), liver ${ }^{26), 30), 31)}$, kidney ${ }^{26), 32 \text { ) }}$ and so on. Polyphenols in green tea consist mainly of four epi-catechins, (-)-epicatechin, $(-)$-epicatechin gallate, (-)-epigallocatechin and (-)-epigallocatechin gallate, and their total 
Table 1. Contents of Polyphenols and Caffeine in TP Preparation

\begin{tabular}{lc}
\hline \multicolumn{1}{c}{ Components } & $(\mathrm{mg} / \mathrm{g})$ \\
\hline (-)-Epigallocatechin gallate & 418.4 \\
(-)-Epigallocatechin & 140.4 \\
(-)-Epicatechin & 54.8 \\
(-)-Epicatechin gallate & 47.2 \\
(+)-Catechin & 15.9 \\
Gallic acid & 2.28 \\
\hline Total content of polyphenols & 679.0 \\
\hline Caffeine & 35.6 \\
\hline
\end{tabular}

content in tea leaves is up to $16-18 \%$ per dry

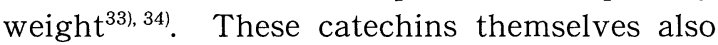
have a strong hypolipidemic action ${ }^{25), 35)}$.

In this study, we investigated the antioxidative and hypolipidemic effects of crude polyphenol extracts from green tea leaves (tea polyphenols, TP) in mice fed a fish oil-rich diet.

\section{Materials and Methods}

\section{Materials}

Stripped corn oil was purchased from Eastman Kodak Co., New York, US. Cod liver oil was from Yamada Seiyaku Co., Ibaragi, Japan. Other chemicals used were of reagent grade.

\section{Preparation of TP from green tea leaves}

Green tea leaves (Yabukita cultivar) were purchased from Fukuyama Seicha Co., Shizuoka, Japan. The leaves $(200 \mathrm{~g})$ were boiled in $6 \mathrm{~L}$ of water for $10 \mathrm{~min}$ then the infusion was filtered through a filter paper and caffeine was removed by extraction with an equal volume of chloroform. The solusion was extracted with an equal volume of ethyl acetate and ethyl acetate layer was evaporated to afford $23.61 \mathrm{~g}$ of crude TP. The contents of polyphenols and caffeine in the above crude TP was determined by the high performance liquid chromatographic method reported previously ${ }^{34)}$. The analytical results are shown in Table 1. The total content of polyphenols in the crude TP was approximately $68 \%$.

\section{Preparation of diet}

A delipidated diet was purchased from Oriental Yeast Co., Ltd., Tokyo, Japan. The components of this diet were based on the AIN-76
Table 2. Diet Composition

\begin{tabular}{|c|c|c|c|}
\hline & $\begin{array}{l}\text { Control } \\
\text { group }\end{array}$ & $\begin{array}{c}\text { FO } \\
\text { group }\end{array}$ & $\begin{array}{c}\mathrm{FO}+\mathrm{TP} \\
\text { group }\end{array}$ \\
\hline \multicolumn{4}{|c|}{ Diet composition $(\mathrm{g} / 100 \mathrm{~g})$} \\
\hline Casein & 20.0 & 20.0 & 19.9 \\
\hline DL-Methionine & 0.3 & 0.3 & 0.3 \\
\hline Corn starch & 15.0 & 15.0 & 14.9 \\
\hline Sucrose & 50.0 & 50.0 & 49.8 \\
\hline Cellulose & 5.0 & 5.0 & 5.0 \\
\hline Mineral mix. & 3.5 & 3.5 & 3.5 \\
\hline Vitamin mix. & 1.0 & 1.0 & 1.0 \\
\hline Choline bitartrate & 0.2 & 0.2 & 0.2 \\
\hline Stripped corn oil & 5.0 & 0.5 & 0.5 \\
\hline Cod liver oil & - & 4.5 & 4.5 \\
\hline $\mathrm{TP}$ & - & - & 0.5 \\
\hline Vitamin E (mg/100 g) & 5.50 & 5.28 & 5.28 \\
\hline \multicolumn{4}{|c|}{ Fatty acid composition (\%) } \\
\hline $16: 0$ & 11.2 & 11.5 & 11.5 \\
\hline $16: 1$ & ND & 1.6 & 1.7 \\
\hline $18: \ln -9$ & 26.4 & 27.5 & 27.2 \\
\hline $18: 2 n-6$ & 62.1 & 16.8 & 17.2 \\
\hline $20: \ln -9$ & 0.3 & 12.5 & 12.4 \\
\hline $20: 5 n-3$ & ND & 12.7 & 12.6 \\
\hline $22: 1 n-9$ & ND & 15.8 & 15.8 \\
\hline $22: 6 n-3$ & ND & 1.6 & 1.6 \\
\hline
\end{tabular}

ND: Not detected. Vitamin $\mathrm{E}$ contents in stripped corn oil and cod liver oil were $100 \mu \mathrm{g} / \mathrm{g}$ and $50 \mu \mathrm{g} / \mathrm{g}$, respectively. Mineral mix. (g/100 g) contained $\mathrm{CaHPO}_{4}, 50 ; \mathrm{NaCl}, 7.4 ; \mathrm{K}_{3} \mathrm{C}_{6} \mathrm{H}_{5} \mathrm{O}_{7}$. $\mathrm{H}_{2} \mathrm{O}, 22 ; \mathrm{K}_{2} \mathrm{SO}_{4}, 5.2 ; \mathrm{MgO}, 2.4 ; \mathrm{MnCO}_{3}, 0.35$; Fe-citrate, $0.6 ; \mathrm{ZnCO}_{3}, 0.16 ; \mathrm{CuCO}_{3} \cdot \mathrm{Cu}(\mathrm{OH})_{2}$ $\mathrm{H}_{2} \mathrm{O}, 0.03 ; \mathrm{Na}_{2} \mathrm{SeO}_{3} \cdot 5 \mathrm{H}_{2} \mathrm{O}, 0.001 ; \mathrm{KIO}_{3}, 0.001$; $\mathrm{CrK}\left(\mathrm{SO}_{4}\right)_{2} \cdot 12 \mathrm{H}_{2} \mathrm{O}, 0.055$. Vitamin mix. (per 100 g) contained vitamin $\mathrm{A} \cdot$ acetate, $40,000 \mathrm{IU}$; vita$\min \mathrm{D}_{3}, 10,000 \mathrm{IU}$; vitamin $\mathrm{E} \cdot$ acetate, $500 \mathrm{mg}$; vitamin $\mathrm{K}_{3}, 0.5 \mathrm{mg}$; vitamin $\mathrm{B}_{1} \cdot \mathrm{HCl}, \quad 60 \mathrm{mg}$; vitamin $\mathrm{B}_{2}, 60 \mathrm{mg}$; vitamin $\mathrm{B}_{6} \cdot \mathrm{HCl}, 70 \mathrm{mg}$; vitamin $\mathrm{B}_{12}, 0.1 \mathrm{mg}$; D-biotin, $2 \mathrm{mg}$; folic acid, 20 mg; Ca pantothenate, $160 \mathrm{mg}$; nicotinic acid, 300 mg.

$\operatorname{diet}^{36)}$. Using this diet, a diet supplemented with $5.0 \%$ stripped corn oil, a diet with $0.5 \%$ stripped corn oil and $4.5 \%$ cod liver oil, and a diet with $0.5 \%$ stripped corn oil, $4.5 \%$ cod liver oil and $0.5 \%$ TP were prepared in our laboratory. Diet compositions are shown in Table 2. In this experiment, the contents of vitamin $\mathrm{E}$ in the three diets were controlled to be in the same range (5.3-5.5\%), and all diets were kept at $-80^{\circ} \mathrm{C}$ until use to avoid lipid auto-oxidation 
Table 3. Effects of Fish Oil and TP Feeding on Body Weight Gain, Final Body Weight, Relative Organ Weight and Food Intake of ddY Mice

\begin{tabular}{lccc}
\hline \multicolumn{1}{c}{ Indexes } & Control & FO group & FO + TP group \\
\hline Numbers of mice & 5 & 9 & 9 \\
Body weight gain $(\mathrm{g})$ & $6.02 \pm 0.82^{\mathrm{a}, \mathrm{b}}$ & $2.69 \pm 0.70^{\mathrm{a}}$ & $1.84 \pm 1.05^{\mathrm{b}}$ \\
Final body weight (g) & $44.4 \pm 2.20^{\mathrm{c}, \mathrm{d}}$ & $39.8 \pm 2.15^{\mathrm{c}}$ & $37.7 \pm 2.30^{\mathrm{d}}$ \\
Final liver weight (\% of body weight) & $4.01 \pm 0.56$ & $3.72 \pm 0.30$ & $3.74 \pm 0.61$ \\
Final kidney weight (\% of body weight) & $0.68 \pm 0.02$ & $0.68 \pm 0.05$ & $0.69 \pm 0.08$ \\
Food intake (g/d/mouse) & 5.22 & 6.94 & 6.85 \\
\hline
\end{tabular}

Significant differences exist between groups having the same superscript: $p<0.05 ; \mathrm{d}, p<0.01 ; \mathrm{a}, \mathrm{b}, \mathrm{c}$.

during storage.

\section{Animals}

Male ddY mice of 8 weeks old (Japan SLC, Inc., Shizuoka, Japan.) were divided into 3 groups, which were given the following diets: (1) a delipidated diet supplemented with 5.0\% stripped corn oil (control group), (2) a diet with $0.5 \%$ stripped corn oil and $4.5 \%$ cod liver oil (FO group) or (3) a diet with $0.5 \%$ stripped corn oil, $4.5 \%$ cod liver oil and $0.5 \% \mathrm{TP}$ (FO+ TP group). The numbers of mice in the groups were 5,9 and 9 , respectively. Four or five mice were housed per plastic cage. To avoid the influence of female hormones on lipid metabolism and antioxidative status $^{37}$, male mice were used. In previous studies, distinct antioxidative and hypolipidemic actions of tea catechins were observed in rats after $2-4$ weeks of feeding ${ }^{35), 38 \text {. }}$ Therefore, mice were killed under anesthesia with diethyl ether at 21 days after the start of feeding in this study.

\section{Analyses}

Body weight of mice was measured at the beginning and the end of experiments. Food intake of each mouse per day was recorded. The liver and kidney were taken and weighed, then homogenized in 19 volumes of $40 \mathrm{mmol} / \mathrm{L}$ phosphate buffer ( $\mathrm{pH} 7.4$ ). Lipids in the liver were extracted by the method of Folch et al. ${ }^{39)}$ Fatty acid compositions of liver lipids were analyzed on a gas-liquid chromatograph (GC-15A, Shima$\mathrm{dzu}$, Tokyo, Japan) equipped with a Unisole 3000 (GL Science Inc., Tokyo, Japan) glass column $(3 \mathrm{~mm}$ i.d. $\times 3 \mathrm{~m})$ at $235^{\circ} \mathrm{C}$. Hepatic lipids were hydrolyzed in $2.0 \mathrm{~mol} / \mathrm{L} \mathrm{NaOH}$ at $50^{\circ} \mathrm{C}$ for 5 min. Formed free fatty acids were extracted with diethyl ether in an acidic condition and methylated with diazomethane according to the method of Boer and Backer ${ }^{40)}$. Fatty acids were identified by the method of Hofstetter et al. ${ }^{41)}$ by comparing with authentic samples purchased from GL Science Inc., Tokyo, Japan. Lipid contents in mouse serum were measured by using kits from Kyowa Medex Co., Ltd., Tokyo, Japan. Total lipid contents were expressed as the sum of triglyceride, total cholesterol and phospholipid. Lipid peroxide contents in mouse serum were determined by the method of Masugi and Nakamura ${ }^{42}$, and those in the liver and kidney, by the method of $\mathrm{Yagi}^{43)}$. Lipid peroxide contents were expressed in terms of malondialdehyde. Vitamin $\mathrm{E}$ contents in the serum, liver and kidney of mice were determined by the method of McGeachin and Bailey ${ }^{44}$.

\section{Statistical analysis}

Statistical analysis was done by the use of Student's $t$-test or Aspin-Welch's modified $t$-test.

\section{Results and Discussion}

Body weight gains, final body weights, relative organ weights, and amounts of food intake of ddY mice are shown in Table 3. Body weight gains and final body weights of the $\mathrm{FO}$ and $\mathrm{FO}+$ TP groups were significantly lower than those of the control group. No significant difference was found between the FO and FO+ TP groups. There was no difference in the relative weights of liver and kidney among the three groups. The suppression of body weight gain has been reported in many studies involving administration of fish oil $\left.\left.\left.\left.\left.{ }^{7,}, 11\right), 17\right), 19\right), 45\right), 46\right)$. Food intake of the $\mathrm{FO}$ and FO + TP groups tended to be higher than that of the control group. 
Table 4. Effects of Fish Oil and TP Feeding on Fatty Acid Composition in Liver Lipids of ddY Mice

\begin{tabular}{cccc}
\hline \hline Fatty acids (\%) & Control & FO group & FO+TP group \\
\hline $16: 0$ & $24.9 \pm 0.49^{\mathrm{a}}$ & $27.5 \pm 1.12^{\mathrm{a}, \mathrm{b}}$ & $23.0 \pm 2.89^{\mathrm{b}}$ \\
$16: 1$ & $\mathrm{ND}$ & $\mathrm{ND}$ & $0.15 \pm 0.02$ \\
$18: 0$ & $12.5 \pm 0.53^{\mathrm{c}, \mathrm{d}}$ & $8.91 \pm 1.77^{\mathrm{c}, \mathrm{e}}$ & $14.6 \pm 0.74^{\mathrm{d}, \mathrm{e}}$ \\
$18: 1 \mathrm{n}-9$ & $23.6 \pm 0.37^{\mathrm{f}, \mathrm{g}}$ & $14.4 \pm 2.68^{\mathrm{f}, \mathrm{h}}$ & $9.40 \pm 0.64^{\mathrm{g}, \mathrm{h}}$ \\
$18: 2 \mathrm{n}-6$ & $30.6 \pm 1.24^{\mathrm{i}, \mathrm{j}}$ & $18.4 \pm 1.09^{\mathrm{i}, \mathrm{k}}$ & $12.1 \pm 2.72^{\mathrm{j}, \mathrm{k}}$ \\
$20: 5 \mathrm{n}-3$ & $16.5 \pm 0.08^{\mathrm{l}, \mathrm{m}}$ & $5.87 \pm 1.64^{\mathrm{l}}$ & $6.39 \pm 1.51^{\mathrm{m}}$ \\
$22: 1 \mathrm{n}-9$ & $1.66 \pm 0.51^{\mathrm{n}, \mathrm{o}}$ & $8.78 \pm 0.96^{\mathrm{n}, \mathrm{p}}$ & $13.6 \pm 2.13^{\mathrm{o}, \mathrm{p}}$ \\
$22: 6 \mathrm{n}-3$ & $4.14 \pm 0.87^{\mathrm{q}, \mathrm{r}}$ & $15.4 \pm 1.63^{\mathrm{q}, \mathrm{s}}$ & $20.5 \pm 4.69^{\mathrm{r}, \mathrm{s}}$ \\
\hline
\end{tabular}

ND: Not detected. Significant differences exist between groups having the same superscript: $p<0.01 ; a^{-}$.

Table 5. Effects of Fish Oil and TP Feeding on Lipid Contents in Serum of ddY Mice

\begin{tabular}{lccc}
\hline \hline Lipids $(\mathrm{mg} / \mathrm{dL})$ & Control & FO group & FO+TP group \\
\hline Triglyceride & $175.1 \pm 44.3^{\mathrm{a}}$ & $155.6 \pm 37.7^{\mathrm{b}}$ & $98.1 \pm 34.9^{\mathrm{a}, \mathrm{b}}$ \\
Total cholesterol & $146.1 \pm 27.6^{\mathrm{c}, \mathrm{d}}$ & $99.5 \pm 19.9^{\mathrm{c}}$ & $90.5 \pm 13.5^{\mathrm{d}}$ \\
Phospholipid & $314.1 \pm 57.6^{\mathrm{e}, \mathrm{f}}$ & $246.0 \pm 36.7^{\mathrm{e}}$ & $226.3 \pm 57.6^{\mathrm{f}}$ \\
Total lipid content & $635.3 \pm 94.6^{\mathrm{g}, \mathrm{h}}$ & $501.2 \pm 72.5^{\mathrm{g}, \mathrm{i}}$ & $414.9 \pm 91.8^{\mathrm{h}, \mathrm{i}}$ \\
\hline
\end{tabular}

Significant differences exist between groups having the same superscript: $p<0.05 ; \mathrm{b}, \mathrm{e}-\mathrm{g}, \mathrm{i}, p<0.01 ; \mathrm{a}, \mathrm{c}$, d, h.

Fatty acid compositions in the liver of ddY mice of the three groups are shown in Table 4. Administration of fish oil to mice increased the contents of n-3 PUFA in the liver. Hu et al. ${ }^{47)}$ and Leibovitz et al. ${ }^{48)}$ also reported similar extents of increase of PUFA contents in the liver of rats fed a fish oil-supplemented diet. Further increases of the contents of n-3 PUFA were observed in the liver of the FO+TP group in this study. This observation suggests that a part of the $n-3$ PUFA in fish oils administered to animals is destroyed, perhaps by oxidation, and that the destruction of n-3 PUFA was inhibited by the additional administration of TP.

Lipid contents in the serum of three groups are shown in Table 5. In the serum of the FO or $\mathrm{FO}+\mathrm{TP}$ group, the contents of total cholesterol and phospholipid were significantly lower than those of the control group. Serum content of triglyceride in the FO+ TP group was much lower than those of the control and FO groups. The total lipid contents in the serum of the FO and $\mathrm{FO}+\mathrm{TP}$ groups were significantly lower than that of control group. The weights of lipid extracted from the liver and kidney of the FO and FO + TP groups also tended to be lower than those of the control group (data not shown). The hypolipidemic action and liver triglyceride- lowering effects of fish oils have been observed in many studies ${ }^{6)-8), 10), 16)-18), 46), 49)}$. Our results. suggest that the addition of $\mathrm{TP}$ to fish oilsupplemented diet could emphasize the hypolipidemic effects of fish oil.

Lipid peroxide contents in the serum, liver and kidney of animals in the three groups are shown in Table 6 . The contents of lipid peroxides in the serum and liver of animals in the FO group were significantly higher than those of the control group, as noted in other reports on the blood $^{8,13), 18), 49)}$ and liver ${ }^{16), 45), 47), 48)}$ of mice and rats. This elevation of lipid peroxide was not observed in the kidney of animals in the FO group. Hu et al. ${ }^{47)}$ also reported that administration of fish oil increased the content of lipid peroxides in rat liver, but not in the kidney. Supplementation of TP to fish oil in the diet lowered the contents of lipid peroxides in the serum, liver and kidney of mice administered fish oil only. TP showed a strong lipid peroxidelowering effect in the kidney, in accordance with our previous study ${ }^{26}$.

Vitamin E contents in the serum, liver, and kidney of animals in the three groups are shown in Table 6. The contents of vitamin $\mathrm{E}$ in the serum, liver, and kidney of the FO group were significantly lower than those of control group. 
Table 6. Effects of Fish Oil and TP Feeding on TBARS and Vitamin E Contents in Serum, Liver, and Kidney of ddY Mice

\begin{tabular}{|c|c|c|c|}
\hline Samples & Control & FO group & $\mathrm{FO}+\mathrm{TP}$ group \\
\hline \multicolumn{4}{|l|}{ TBARS } \\
\hline Serum $(\mathrm{nmol} / \mathrm{mL})$ & $11.8 \pm 1.30^{\mathrm{a}}$ & $19.6 \pm 7.23^{\mathrm{a}, \mathrm{b}}$ & $11.7 \pm 3.04^{b}$ \\
\hline Liver (nmol/g) & $215.8 \pm 12.9^{c, d}$ & $327.2 \pm 67.4^{\mathrm{c}, \mathrm{e}}$ & $195.1 \pm 16.5^{\mathrm{d}, \mathrm{e}}$ \\
\hline Kidney (nmol/g) & $282.6 \pm 35.3^{f}$ & $237.3 \pm 28.6^{\mathrm{g}}$ & $94.7 \pm 32.6^{\mathrm{f}, \mathrm{g}}$ \\
\hline \multicolumn{4}{|l|}{ Vitamin $E$} \\
\hline Serum $(\mu \mathrm{g} / \mathrm{mL})$ & $5.88 \pm 1.83^{\mathrm{h}}$ & $2.45 \pm 1.17^{\mathrm{h}}$ & $4.20 \pm 2.40$ \\
\hline Liver $(\mu \mathrm{g} / \mathrm{g})$ & $22.3 \pm 6.07^{\mathrm{i}, \mathrm{j}}$ & $4.90 \pm 2.04^{\mathrm{i}}$ & $7.41 \pm 6.62^{\mathrm{j}}$ \\
\hline Kidney $(\mu \mathrm{g} / \mathrm{g})$ & $6.63 \pm 0.65^{\mathrm{k}, 1}$ & $3.79 \pm 0.73^{\mathrm{k}, \mathrm{m}}$ & $5.05 \pm 0.94^{1, m}$ \\
\hline
\end{tabular}

Significant differences exist between groups having the same superscript: $p<0.05 ; \mathrm{a}-\mathrm{e}, \mathrm{g}, \mathrm{i}, \mathrm{j}, p<0.01 ; \mathrm{f}, \mathrm{h}$, $\mathrm{k}-\mathrm{m}$.

Cho and Choi ${ }^{13)}$, Alexander et $a l^{19)}$ and Reddy and Lokesh ${ }^{12)}$ reported that the administration of fish oil decreased the contents of vitamin $\mathrm{E}$ in rat plasma and liver to $5-29 \%$ and $14-50 \%$ of the control values, respectively. No significant difference was found in the serum levels of the control and the FO+TP group. Supplementation of TP to fish oil in the diet also tended to inhibit the decrease of vitamin $E$ level in the liver of mice. In the kidney, the level of vitamin $\mathrm{E}$ in the FO+ TP group was significantly higher than that of the FO group.

These results suggest that TP, strong antioxidants, prevent in vivo consumption of vitamin $\mathrm{E}$ caused by fish oil. TP may play an important antioxidant role in the stocked diet, as well as in the blood and organs of mice. We have already reported that $\mathrm{TP}$ could inhibit the peroxidation of cod liver oil in vitro ${ }^{22), 23)}$. The mechanisms of the effects in the blood and organs of mice, however, have not been investigated enough in this study. Recently, studies on the absorption of tea catechins in rat and human ${ }^{50-54)}$ have demonstrated that small amounts of catechins were detected in the bloodstream in free as well as conjugated forms after administration. In this study, we tried to determine free catechins in the serum and organs of mice given the fish oil plus TP-supplemented diet, using the method previously reported ${ }^{34)}$. The lower limit of quantitation was approximately $1.0 \mathrm{ng}$ in this method. However, no free catechins were detected in the serum, liver, or kidney of the FO+ TP group. Therefore, these in vivo effects of TP might not be directly associated with intact TP.
Khan et al. ${ }^{55)}$ demonstrated that $\mathrm{TP}$ administration to mice elevated the activities of phase II enzymes, catalase (EC 1.11.1.6), glutathione peroxidase (EC 1.11.1.9), and glutathione Stransferase (EC 2.5.1.18) in the liver. However, Galvez et al..$^{31)}$ found that the administration of (-)-epicatechin had no effect on the activities of glutathione-related enzymes in rat liver. We determined the contents of reduced glutathione in the liver and kidney of animals of the three groups. The contents of reduced glutathione in the liver and kidney in the FO group were significantly lower than those in the control group. This decrease of reduced glutathione was not improved by additional TP administration (data not shown). It is, therefore, difficult to suppose that glutathione-related enzymes function more effectively in the organs of the $\mathrm{FO}+\mathrm{TP}$ group in comparison with those of the FO group. These results may suggest that metabolites or different forms of TP produced in the animal body exhibit.high antioxidative activity, comparable to that of intact TP.

In conclusion, TP seem to be valuable additives to a fish oil-supplemented diet for enhancement of the hypolipidemic effect and antioxidative function, though the mechanisms of their effects need to be investigated further.

\section{References}

1) Leaf, A., Weber, P. C.: N. Engl. J. Med. 318, 549557 (1988).

2) Simopoulos, A. P.: Am. J. Clin. Nutr. 54, 438-463 (1991).

3) Chen, M. F., Hsu, H. C., Lee, Y. T.: Clin. Sci. 89, 
497-504 (1995).

4) Charnock, J. S., MeLennan, P. L., Abeywardena, M. Y., Dryde, W. F.: Ann. Nutr. Metab. 29, 306318 (1985).

5) Hobbs, L. M., Rayner, T. E., Howe, P. R. C.: Clin. Exp. Pharmacol. Physiol. 23, 508-513 (1996).

6) Harris, W. W., Connor, W. E.: Trans. Assoc. Am. Physicians 43, 148-152 (1980).

7) Innis, S. M., Rioux, F. M., Auestad, N., Ackman, R. G.: J. Nutr. 125, 2,286-2,293 (1995).

8) Luostarinen, R., Wallin, R., Wibell, L., Saldeen, T.: Nutr. Res. 15, 953-968 (1995).

9) Panzetta, O., Cominacini, L., Garbin, U., Pasini, A. F., Gammaro, L., Bianco, F., Davoli, A., Campagnola, M., Santis, A. D., Pastorino, A.M., Cascio, V. L.: Clin. Nephrol. 44, 303-309 (1995).

10) Nardini, M., D’Aquino, M., Tomassi, G., Gentili, V., Felice, M. D., Scaccini, C.: J. Nutr. Biochem. 6, 474-480 (1995).

11) Nair, P.P., Judd, J. T., Berlin, E., Taylor, P. R., Shami, S., Sainz, E., Bhagavan, H. N.: Am. J. Clin. Nutr. 58, 98-102 (1993).

12) Reddy, A. C. P., Lokesh, B. R.: J. Nutr. Biochem. 5, 181-188 (1994).

13) Cho, S. H., Choi, Y.-S.: Lipids 29, 47-52 (1994).

14) Kubow, S., Goyette, N., Kermasha, S., StewartPhillip, J., Koski, K. G.: ibid. 31, 839-847 (1996).

15) Wander, R. C., Du, S.-H., Ketchum, S. O., Rowe, K. E.: J. Nutr. 126, 643-652 (1996).

16) Kobatake, Y., Kuroda, K., Jinouchi, H., Nishide, E., Innami, S.: J. Nutr. Sci. Vitaminol. 29, 11-21 (1983).

17) Mounie, J., Faye, B., Magdalou, J., Goudonnet, H., Truchot, R., Siest, G.: J. Nutr. 116, 2,034-2,043 (1986).

18) Meydani, M., Natiello, F., Goldin, B., Free, N., Woods, M., Shaefer, E., Blumber, J. B., Gorbach, S. L.: ibid. 121, 484-491 (1991).

19) Alexander, D. W., McGuire, S. O., Cassity, N. A., Fritsche, K. L.: ibid. 125, 2,640-2,649 (1995).

20) Ramanathan, L., Das, N. P.: J. Agric. Food Chem. 40, 17-21 (1992).

21) Frankel, E. N., Huang, S.-W., Prior, E., Aeschbach, R.: J. Sci. Food Agric. 72, 201-208 (1996).

22) Goto, T., Yoshino, K., Sano, M., Tomita, I., Murata, H.: Nippon Suisan Gakkaishi 62, 677678 (1996).

23) Goto, T., Nagaike, T., Kuribayashi, H., Yoshino, K.: Numazu Coll. Technol. Res. Ann. 31, 93-95 (1997).

24) Fraga, C. G., Martino, V. S., Ferraro, G. E., Coussio, J. D., Boveris, A.: Biochem. Pharmacol. 36, 717-720 (1987).

25) Yoshino, K., Tomita, I., Sano, M., Oguni, I., Hara, Y., Nakano, M.: Age 17, 79-85 (1994).
26) Sano, M., Takahashi, Y., Yoshino, K., Shimoi, K., Nakamura, Y., Tomita, I., Oguni, I., Konomoto, H.: Biol. Pharm. Bull. 18, 1,006-1,008 (1995).

27) Matsuzaki, T., Hara, Y.: Nippon Nōgeikagaku Kaishi 59, 129-134 (1985).

28) Yoshino, K., Hara, Y., Sano, M., Tomita, I.: Biol. Pharm. Bull. 17, 146-149 (1994).

29) Nanjo, F., Honda, M., Okushio, K., Matsumoto, N., Ishigaki, F., Ishigami, T., Hara, Y.: ibid. 16, 1,156-1,159 (1993).

30) Uchida, S., Ozaki, M., Suzuki, K., Shikita, M.: Life Sci. 50, 147-152 (1992).

31) Galvez, J., Cruz, J. P. D. L., Zasrzuelo, A., Cuesta, F. S. D. L.: Pharmacology 51, 127-133 (1995).

32) Yokozawa, T., Oura, H., Sakanaka, S., Kim, M.: Biosci. Biotechnol. Biochem. 56, 896-899 (1992).

33) Terada, S., Maeda, Y., Masui, T., Suzuki, Y., Ina, K.: Nippon Shokuhin Kogyo Gakkaishi 34, 2027 (1987).

34) Yoshino, K., Hara, Y.: Numazu Coll. Tech. Res. Ann. 27, 87-91 (1992).

35) Muramatsu, K., Fukuyo, M., Hara, Y.: J. Nutr. Sci. Vitaminol. 32, 613-622 (1986).

36) American Institute of Nutrition: J. Nutr. 107, 1,340-1,348 (1977).

37) Yoshino, K., Komura, S., Watanabe, I., Nakagawa, Y., Yagi, K.: J. Clin. Biochem. Nutr. 3, 233-240 (1987).

38) Hasegawa, R., Chujo, T., Sai-kato, K., Umemura, T., Tanimura, A., Kurokawa, Y.: Fd Chem. Toxic. 33, 961-970 (1995).

39) Folch, J., Ascoli, I., Lees, M., Meath, J. A., Lebaron, F. N.: J. Biol. Chem. 191, 833-841 (1951).

40) Boer, T. J. D., Backer, H. J.: Org. Synth. IV, 250 (1963).

41) Hofstetter, H. H., Sen, N., Holman, R. T.: J. Am. Oil Chemists' Soc. 42, 537-540 (1965).

42) Masugi, F., Nakamura, T.: Vitamins 51, 21-29 (1977).

43) Yagi, K.: Biochem. Med. 15, 212-216 (1976).

44) McGeachin, R. B., Bailey, C. A.: Poul. Sci. 74, 407-411 (1995).

45) Skuladottir, G. V., Shi-Hua, D., Brodie, A. E., Reed, D. J., Wander, R. C.: Lipids 29, 351-357 (1994).

46) Geelen, M. J. H., Schoots, W. J., Bijleveld, C., Beynen, A. C.: J. Nutr. 125, 2,449-2,456 (1995).

47) Hu, M.-L., Frankel, E. N., Leibovitz, B. E., Tappel, A. L.: ibid. 119, 1,574-1,582 (1989).

48) Leibovitz, B. E., Hu, M.-L., Tappel, A. L.: Lipids 25, 125-129 (1990).

49) Haglung, O., Luostarinen, R., Wallin, R., Wibell, L., Saldeen, T.: J. Nutr. 121, 165-169 (1991).

50) Lee, M.-J., Wang, Z.-Y., Li, H., Chen, L., Sun, Y., Gobbo, S., Balentine, D. A., Yang, C. S.: Cancer 
Epidemiol. Biomarkers Prevent 4, 393-399 (1995).

51) Unno, T., Takeo, T.: Biosci. Biotechnol. Biochem. 59, 1,558-1,559 (1995).

52) Wang, Z. Y., Wang, L.-D., Lee, M.-J., Ho, C.-T., Huang, M.-T., Conney, A. H., Yang, C. S.: Carcinogenesis 16, 2,143-2,148 (1995).

53) Okushio, K., Matsumoto, N., Kohri, T., Suzuki,
M., Nanjo, F., Hara, Y.: Biol. Pharm. Bull. 19, 326-329 (1996).

54) Unno, T., Kondo, K., Itakura, H., Takeo, T.: Biosci. Biotechnol. Biochem. 60, 2,066-2,068 (1996).

55) Khan, S. G., Katiyar, S. K., Agarwal, R., Mukhtar, H.: Cancer Res. 52, 4,050-4,052 (1992). 